\title{
An empirical study of third-party purchase: New Zealand users’ perspective
}

\author{
Yangyan Shi ${ }^{\mathrm{a}, \mathrm{b}}$, Tiru Arthanaric ${ }^{\mathrm{c}}$ Lincoln C. Wood ${ }^{\mathrm{d}, \mathrm{e}}$
}

a. School of Economics and Management, Shanxi University, Shanxi, China, 213164

Tel: (86)519 86330550; Email: yshi@cczu.edu.cn

b. Centre for Supply Chain Management, University of Auckland Business School, Auckland, New Zealand

c. Department of Information Systems and Operations Management, University of Auckland Business School, Auckland, New Zealand

Tel:(64) 9923 4857; E-mail: t.arthanari@auckland.ac.nz

d. Graduate School of Management, University of Auckland Business School, Auckland, New Zealand

Tel: (64) 9923 5820; E-mail: L.Wood@auckland.ac.nz

e. School of Information Systems, Curtin University, Bentley, Australia

\begin{abstract}
This paper investigates the potential for third-party purchase (3PP) services offered by third-party logistics (3PL) providers, from the perspective of 3PL users, based on transaction cost analysis. We conducted a survey of New Zealand 3PL users and received 163 usable responses. Structural equation modelling was used to test the conceptual model. We found that 3PL users are more likely to adopt 3PP service when there is greater uncertainty. Asset specificity, frequency, and transaction size do not have a significant relationship with 3PP service adoption. However, 3PP service is significantly related to the value-to-client and benefit-to-3PL provider. This study is pioneering research on 3PP service as a value-added service offered by 3PL providers, from the perspective of 3PL users. The findings suggest that offering 3PP service will provide mutual benefits and value for both 3PL users and their 3PL providers.
\end{abstract}

Keywords: third-party logistics (3PL); third-party purchase (3PP); transaction cost analysis; structural equation modelling; 3PL users; New Zealand 


\section{Introduction}

While purchasing is a crucial component in the success of firms, Small- and Medium-sized Enterprises (SMEs) usually do not have the same bargaining power as large firms and this impacts on their ability to negotiate lower prices. The asymmetrical position for SMEs makes them unattractive as trading partners because of high risk and relevant transaction costs. Most executives of small firms rely on individual traits when selecting suppliers, including personal characteristics, age, education, and work experience. The selection processes are subjective and lack the application of more rigorous institutional procedures applied large firms when looking for appropriate suppliers (Park and Krishnan, 2001). Sourcing is a challenge faced by SMEs due to limited managerial and capital resources (Scully and Fawcett, 1994). Most SMEs need to outspend large firms to achieve success, and struggle to find an appropriate international supplier. The profit margin may shrink due to an increase in procurement costs and related relationship issues (Ellegaard, 2006). A lack of innovation is another issue of purchasing for SMEs; many firms are unaware of the importance of purchasing, and how their diminished purchasing power may result in them being 'price takers' rather than 'price makers' (Holter et al., 2008). Thus, many SMEs want to find a third-party to manage their purchasing activities (Ellegaard, 2006). This paper examines the potential for thirdparty logistics (3PL) providers to benefit by offering third-party purchase (3PP) services.

The issues addressed in this paper are important for several reasons. First, 3PP as a service is attractive to SMEs as they lack large purchasing volumes when acting independently, providing the opportunity to obtain a better purchasing price, relative to acting alone (Rozemeijer, 2000). 3PP is a form of group purchasing among firms where purchase costs are reduced through aggregating similar purchase orders (Schotanus and Telgen, 2007). By developing 3PP capabilities, 3PLs can play constructive, value-adding roles, in otherwise dyadic relationships (Adobor and McMullen, 2014). While the tactic of group purchasing has been long implemented (Tella and Virolainen, 2005), the 
commercial opportunity to offer 3PP services has attracted little attention from 3PL providers, despite Leuschner et al. (2014) indicating that such collaborative relations with 3PLs can boost performance via these types of innovation.

Second, innovation remains an understudied construct in 3PLs (Arlbjørn \& Paulraj, 2013). It remains unclear how firms should design and control processes to enable the effective creation of value in the supplier-customer relationship (Wagner et al., 2010; Schoenherr et al., 2012, p. 4575). The meta-analytic review by Leuschner et al. (2014) indicated that developing such additional sources of value through innovative offerings is crucial (Leuschner et al., 2014); as some customer segments require innovation as an attribute of 3PLs rather than just price (Anderson et al., 2011). This may require a long-term orientation and a relational approach (Selviaridis and Spring, 2010), while allowing the 3PL to improve their market positioning (Wagner and Sutter, 2012).

Therefore, the purpose of this research is to empirically study 3PP implemented as a value-added service offered by 3PL providers. The empirical research is conducted in New Zealand among 3PL users and identifies 3PL users' perceptions of 3PP service offered by their 3PL providers. There are several motivations for this study: first, building close collaborative relationships with 3PL providers is important to 3PL users, particularly SMEs (Zheng et al., 2007). Second, few studies focus on purchase and supply management in the New Zealand business environment. Third, the majority of New Zealand businesses are SMEs, and they have realized the importance of outsourcing non-critical activities to a professional third-party. Lastly, the New Zealand logistics industry is quite competitive, and 3PL providers are actively seeking new value-added services to differentiate themselves. 3PP is one alternative considered by 3PL providers.

This study aims to address the following three research questions: 1) What are the impacts of asset specificity, uncertainty, frequency, and transaction size on the possibility of 3PL users using 3PP services offered by 3PL providers? 2) What are the benefits for 3PL providers if they want to 
include 3PP service? 3) What are the values for 3PL users if their providers include 3PP service? We use structural equation modelling (SEM) for data analysis.

This paper is structured as follows. We introduce the research model and formulate the hypotheses in section 2, present the research methodology in section 3, show the analysis and discussions in section 4, and provide a conclusion of the paper and suggest topics for future research in section 5 .

\section{Conceptual model and hypotheses}

\subsection{Logistics in New Zealand}

New Zealand is a geographically isolated country where SMEs are important to the national economy. Based on the data provided by New Zealand Inland Revenue (2010), there are 665,000 SMEs producing about 37\% of New Zealand's total output of goods and services. Many local 3PL users are seeking a third-party purchase (3PP) provider to outsource their purchases activities to (Ellegaard, 2006). However, they doubt the ability of 3PL providers to meet the required service levels (Lambert et al., 1999). New Zealand 3PL providers believe that outsourcing service has very low penetration in New Zealand's markets because a lot of 3PL users actually want, for example, to keep their own warehouse and cannot, therefore, realize the importance and benefits for using outsourcing services (Sankaran et al. 2002). This is often cited as a concern over the loss of control, a worry more prevalent among larger firms (Zhang, 2009). However, the involvement of external parties can add value to logistics activities for client firms (Win, 2008).

Currently, more and more New Zealand 3PL users realize the importance to contract out their non-logistics activities to 3PL providers. There are three major reasons (Light, 2001): first, companies are struggling with competition and their inability to keep margins, so they need to consider their core competences. Second, 3PL providers have strong advanced technology to 
maintain their customers. Third, 3PL users can release capital into other areas when they outsource parts of their businesses to the logistics providers.

New Zealand firms' use of 3PLs has similarities and differences with patterns observed in other countries. While the larger New Zealand firms emphasise cost reduction (Zhang 2009), this is similar to what (Arroyo et al., 2006) observe for European and American firms. Arroyo et al. (2006) note that the smaller Mexican firms focus on enhancing their customer service, and the prevalence of SMEs in the domestic market may drive a similar focus on the use of 3PLs in New Zealand. However, this effect may not be driven by the firm size, and other market factors may be significant, such as the differences in national logistics systems and infrastructure that are apparent between countries (Bookbinder and Tan, 2003). Sohail et al. (2006) showed that Singapore firms focused on flexibility for domestic operations while Malaysian firms emphasised time-savings and customer service and an international outlook. In the 1990s, Australian firms were less satisfied with 3PL driven improvements in cost, performance, and customer satisfaction than European and US firms were, showing the early awareness of 3PL relationship management challenges (Millen et al., 1997). Establishing what should be outsourced, which companies should become outsourcing partners, and how the relationships are managed, appear to have been commonly cited reservations about the use of 3PLs in the US and Europe in the early 1990s (Lieb et al., 1993) and similar themes emerge in the New Zealand firms' use of 3PLs (Zhang 2009).

\subsection{Model development}

Transaction cost analysis (TCA; or transaction cost economics [TCE]) is employed in this study as a theoretical basis. Based on TCA, the shift in management has been to consider the 'make' or 'buy' decision. The transaction cost of outsourcing (i.e., buying) is theoretically offset by the benefits of supply chain management, according to combination of offering adding value (Smyth, 2005). Presently, TCA has been widely used at the transaction level (Anderson, 1985; Maltz, 1993; Masten, 
1984; Mclvor, 2009). In contrast, this study researches a core business function at the firm-level: procurement.

The foundations of TCA were developed by Coase (1937) and later formalized by Williamson (1975, 1985, 2008). There are three major variables that impact on transactions: asset specificity, uncertainty, and transaction frequency. Asset specificity refers to an exchange that may require a party to invest in significant investment related to the transaction. Uncertainty means the degree of forecasting future events. Transaction frequency represents the level of asset utilization and deals with the issue of scale economy. This dimension addresses the target of economizing the sum of transaction costs (Bienstock and Mentzer, 1999). The fixed cost per transaction is decreased when transaction frequency increases. We also include the variable of transaction size since it deals with the economies of scale of transactions (Verwaal and Donkers, 2003). The costs of transactionspecific investments can be "easier to recover for large transactions of a recurring kind" (Williamson, 1985, p. 60).

Several researchers have used TCA as a tool to analyse fundamental services implemented by 3PL providers, such as warehousing and transportation (Hanna and Maltz, 1998; Bienstock and Mentzer, 1999; Maltz, 1993, 1994; Mclvor, 2009). It is an important theoretical basis as "TCE (specifically fear of opportunism) exerts it influence on the extent to which procurement activities are outsourced” (Brewer et al., 2014, p. 192). This research focuses on 3PP as a value-added service offered by 3PL providers. As discussed earlier, we consider four control variables: asset specificity, uncertainty, transaction frequency, and transaction size. Figure 1 shows the conceptual model of this research. 


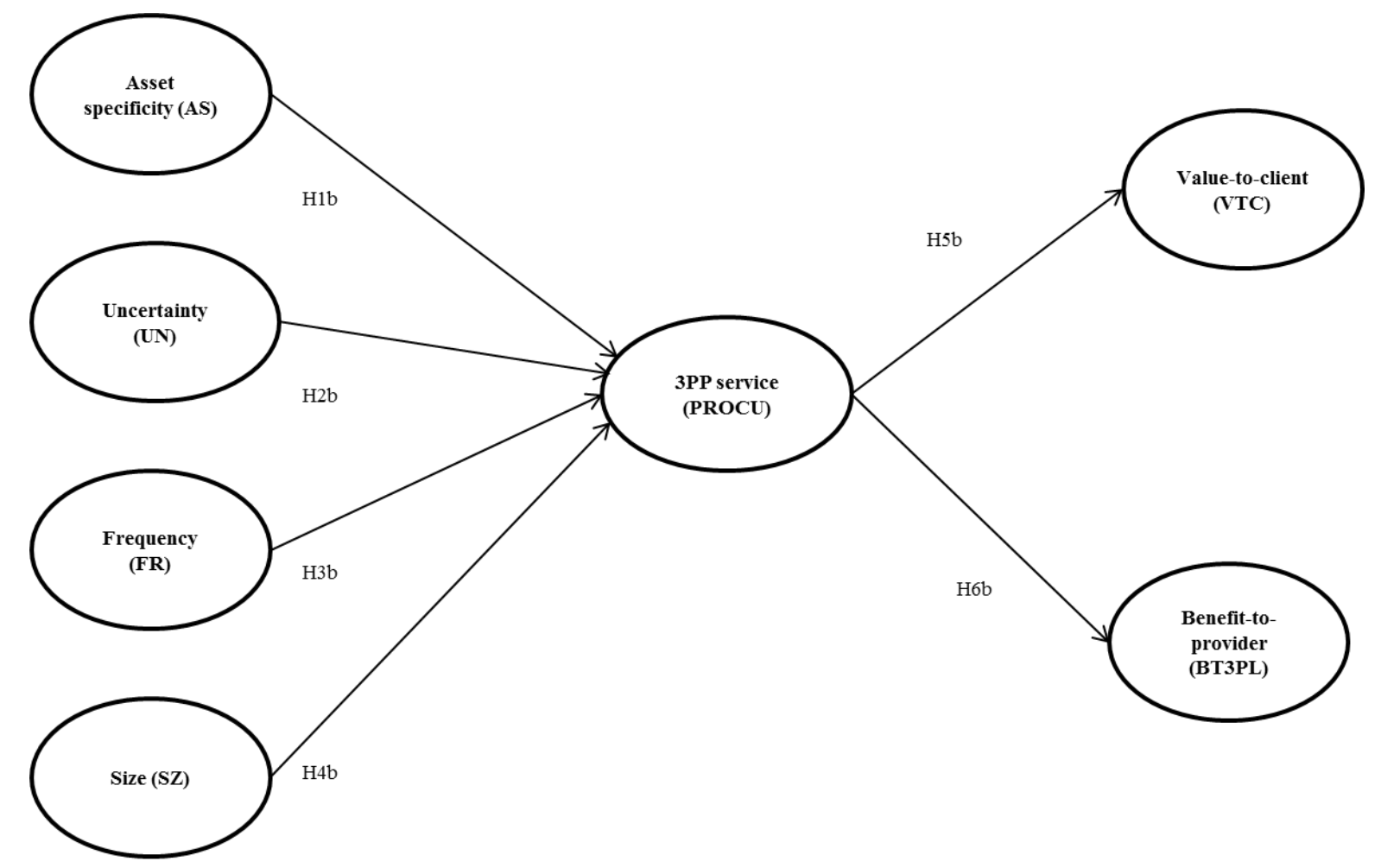

Figure 1 A conceptual model for 3PP. (The shortened variable names as used in the analysis are indicated in parentheses for each variable.)

\section{$\underline{\text { Asset specificity }}$}

Williamson (2008) proposes that "outsourcing properly includes outside procurement for both generic goods and services” (p. 10). 3PL users might outsource its purchasing activities when the asset specificity is low, because high asset specificity leads to less attractiveness to use governance of markets. As a result, firm governance is more favored to minimize transaction costs (Grover and Malhotra, 2003). Therefore, 3PL users may use 3PP service when the investment of asset specificity on purchasing is low. Thus, it is predicted:

H1: The usage of 3PP service by 3PL users is negatively related to purchasing asset specificity.

\section{Uncertainty}


3PL users' perceptions of uncertainty can be influenced by different variables of the environment; e.g., downstream market demand, the ability of logistics providers, and the level of customer service. High uncertainty leads to high transaction costs, so 3PL users need to get greater control to reduce such costs. Vertical integration to implement control adopted by 3PL users can reduce high transaction costs. 3PL users do not want to outsource a function (e.g., purchasing) to a third party when the associated uncertainty is much higher than expected. Therefore, it is predicted:

H2: If uncertainty is low, then 3PL users will use such 3PP service.

\section{Frequency}

As the transaction frequency of consolidated purchasing of similar products on behalf of a number of 3PL users increases, 3PL providers are able to use this leverage so that 3PL users receive more benefits. This is analogous to the frequency variable of Williamson (1985) in the make-or-buy context. 3PL users may not receive more benefits if 3PL providers cannot offer large amounts of purchasing services, quickly consolidate orders, and/or fully use the capacity of shipments. Thus, we predict:

H3: If the frequency of placing purchase orders is high, then 3PL users will use such 3PP service.

\section{$\underline{\text { Transaction size }}$}

In terms of procurement, single firms, such as SMEs, could be deemed to be asymmetrically positioned when undertaking international sourcing. Wilson and Roy (2009) highlight five primary obstacles to effective SME procurement: small purchasing quantity, lack of strong negotiating power, issues around supplier reliability, the lack of support from suppliers, and geographical distance. Due to volume consolidation by 3PL providers, the number of transactions for 3PL users may decrease since they do not need to deal with multiple suppliers, and the associated costs (e.g., 
searching and bargaining costs) are reduced (Vining and Globerman, 1999). Therefore, it is predicted:

H4: If 3PL providers have the capability to create larger size transactions, then 3PL users will use such 3PP service.

\section{$\underline{\text { Value-to-client }}$}

The hybrid institution is the 'in between' situation of market and hierarchy, and outsourcing is incurred in this context (Williamson, 2008, 1985). The advantageous of outsourcing helps 3PL users focus on their core competence. Outsourcing purchasing functions for non-critical items to a 3PL provider helps 3PL users reduce purchasing costs based on the implementation of group purchasing power performed by the 3PL provider (Hudson and McArthur, 1994). Also, 3PL users can share the providers' transportation capacity since a single company, like an SME, may still need to pay full price for the whole container although it could not use the full capacity. Consolidated delivery enables 3PL users to share the transportation capacity and thereby reduce the share of costs. Offering 3PP service helps 3PL providers improve logistics service. Thus, it is predicted:

H5: 3PL providers perceive that 3PP service is positively associated with bringing more value to their clients.

\section{Benefit-to-provider}

3PL users expect that 3PL logistics providers can receive additional profits through implementing 3PP services. Consolidating purchasing orders together can increasingly utilize the capacity of their transportation and warehousing to reduce their operational costs (Ansari and Modarress, 2010). 3PL users perceive that offering 3PP service helps 3PL providers implement an integrated business from purchase to logistics, improve their market position, and attract more customers. Thus, it is predicted: 
H6: 3PL users perceive that 3PP service is positively associated with bringing more benefits to their 3PL providers.

\section{Research methodology}

\subsection{Survey instrument}

We designed a survey to test the perception of 3PL users regarding 3PP services offered by 3PL providers, based on transaction cost perspective discussed in the previous section. The survey was developed in two steps. First, we formulated the questions based on existing literature. Second, we discussed the paper-based survey with academic colleagues, made some changes, and then we discussed the revised survey with middle- and senior-ranked Purchasing Managers at 3PL users. The survey was further refined according to their comments to improve the clarity of the questions. Reviews by both academics and practitioners were to provide face validity (Cook and Campbell, 1979). Links to the electronic and web-based survey were used distributed to collect the data.

\subsection{Measures}

We measured asset specificity based on coordination with 3PL providers, products' competitive positioning, investments in purchasing resources (e.g., time and effort), and transferring organization routines and working procedures (Larsen, 2000; Rabinovich et al., 2007). The uncertainty scales measured the demand forecasting ability, confidence in achieving objectives, the certainty of meeting service requirements, and confidence in changes of purchasing demand (Rabinovich et al., 2007; Reeves et al., 2010). The frequency scales measured several items to capture the frequency in terms of the variables of costs and levels of negotiation power conducted by 3PL providers to reduce purchasing costs (Goldsby and Eckert, 2003; Maltz, 1993; Hanna and Maltz, 1998; Ellram and Billington, 2001). Transaction size measures primarily focused on the ability to combine purchasing 
orders, purchasing power, and trust of purchasing consolidation (Ernst and Bas, 2003; Ellram and Billington, 2001; Stump, 1995; Gattorna et al., 1991).

The 3PP service scales measured a classification of the purchasing function into the following activities: category management, supplier market research, supplier qualification and selection, request for proposal management, bid preparation and management, cost analysis, and supplier relationship management (Pring, 2006). Value-to-client was measured by 3PP's contribution to the reduction of outsourcing cost and employee base and the improvements in flexibility, service levels, ability to focus on core competence, and relationships with 3PL providers (Hofer et al., 2009; Sink and Langley, 1997). The benefit-to-provider scales measured sharing purchasing risk, degrees of successfully outsourcing purchasing activities, and comfort in working with customers (Hofer et al., 2009; Salleh et al., 2009; Knemeyer and Murphy, 2005).

\subsection{Data collection}

For data collection in New Zealand, the distribution of the survey in the research was supported by the Chartered Institute of Procurement and Supply (CIPS) and Centre for Supply Chain Management (CSCM). The associations' members have relevant qualifications and work experience in procurement and logistics. For data collection from CIPS, the Institute administrated the survey process internally and distributed the surveys to their members using newsletters, emails, and websites. We secured the contact details for CSCM members from the director. We sent a participant information sheet and online survey link to the members by emails. Also, we privately contacted some SMEs in New Zealand, obtained their assent to joining this research, and invited them by email to complete the survey. We received a total of 163 usable responses from 3PL users (a response rate of $24.5 \%)$. It is comparable to other reported response rates under similar circumstances (23.1\% response rate by Panayides and So, 2005; 22\% response rate by Rahman, 2008). 


\subsection{Non-response bias and common methods bias}

We examined the non-responses bias and common-method variance suggested by Armstrong and Overton (1977) and Podaskoff and Organ (1986). Based on demographic variables (e.g., firm size, years partnered with 3PL providers, and annual gross sales), we compared the survey of the first $10 \%$ of respondents with those of the last $10 \%$ of respondents using a t-test. The outcome showed no statistical significance between the two groups in terms of the means for items, so there is no nonresponse bias.

For common method variance, the Harman one-factor test was used (Podsakoff and Organ, 1986). All items making up the constructs were entered into a principal components factor analysis with VARIMAX rotation (Gotzamani et al., 2010). The Kaiser-Meyer-Olkin (KMO) measure of sampling adequacy for 3PL users was 0.783, higher than the required threshold of 0.5 (Kaiser, 1970). Bartlett's Test of Sphericity was significant ( $<<0.001)$, suggesting suitability for factor analysis. In the 3PL user data, the results showed that seven factors were responsible for $71.84 \%$ of the variance, and the contribution of the first factor was $16.1 \%$. Thus, common-method variance is not an issue with the data.

\section{Analysis and discussion}

\subsection{Respondent profiles}

Table 1 shows the demographics of the respondents. In the data of 3PL users, $14.7 \%$ of the respondents are from the food, beverage, and wine industry. $12.9 \%$ of respondents are from the public administration and health industry, and 9.8\% are from the retail/wholesale and construction industries. $57.7 \%$ of respondents indicate the duration of their relationship with 3PL providers is 215 years. 22.1\% of 3PL users indicate that they have used 3PL services for more than 15 years. $37.4 \%$ of 3PL users indicate that they have less than 50 full-time employees. $23.9 \%$ of 3PL users indicated their annual gross revenues are less than NZ\$5 million. 
Table 1 Company profile*

\begin{tabular}{|c|c|c|}
\hline Firm characteristics & Firm Group & $\begin{array}{l}\text { Percentage } \\
\text { (3PL users) }\end{array}$ \\
\hline \multirow[t]{12}{*}{ Industry } & Retail/Wholesale & 9.8 \\
\hline & Agriculture & 11 \\
\hline & Construction & 9.8 \\
\hline & Mechanical manufacturing & 7.4 \\
\hline & Petrochemical & 3.7 \\
\hline & Electrical/Engineering & 6.1 \\
\hline & Electronics & 6.7 \\
\hline & Food/Beverage/Wine & 14.7 \\
\hline & Textile and Apparel & 5.5 \\
\hline & Public admin/Health & 12.9 \\
\hline & Education & 5.5 \\
\hline & Other & 6.7 \\
\hline \multirow{5}{*}{$\begin{array}{l}\text { Age of firms partnered } \\
\text { with 3PL providers }\end{array}$} & Less than or equal to 2 years & 20.2 \\
\hline & More than 2 years but less than or equal to 5 years & 16 \\
\hline & More than 5 years, but less than or equal to 10 years & 23.3 \\
\hline & More than 10 years, but less than or equal to 15 years & 18.4 \\
\hline & More than 15 years & 22.1 \\
\hline \multirow[t]{6}{*}{ Number of employees } & Less than 50 & 37.4 \\
\hline & $51-100$ & 52.1 \\
\hline & $101-500$ & $10.4^{*}$ \\
\hline & $501-1000$ & - \\
\hline & $1001-2000$ & - \\
\hline & Over 2000 & - \\
\hline \multirow[t]{5}{*}{ Annual gross sales } & Less than or equal to NZ\$ 5 million & 23.9 \\
\hline & More than NZ\$ 5 million, but less than or equal to NZ\$ 10 million & 17.8 \\
\hline & More than NZ\$ 10 million, but less than or equal to NZ\$ 15 million & 30.1 \\
\hline & More than NZ\$ 15 million, but less than or equal to NZ\$ 20 million & 24.5 \\
\hline & More than NZ\$ 20 million & 3.7 \\
\hline
\end{tabular}

Table 2 Perceived level of importance of outsourcing activities

\begin{tabular}{lc}
\hline \multicolumn{1}{c}{ Activity } & Percentage (3PL users) \\
\hline Transportation & 74.23 \\
Warehousing & 62.58 \\
Purchasing & 52.76 \\
Consolidation and distribution & 58.9 \\
Inventory management & 57.06 \\
Product returns & 44.17 \\
Order management & 42.94 \\
Cross docking & 33.13 \\
Packaging & 44.17 \\
\hline
\end{tabular}

* The annual gross sales for each of these firms are less than NZ\$20 million, so we deem them to be SMEs based on the report of the Economic Development Indicator issued by the New Zealand government and the definition of SMEs reported by Economic Cooperation and Development (OECD). 
Table 2 shows the importance of outsourcing services perceived by 3PL users. Transportation and warehousing as basic services are the most important services perceived by 3PL users. More than half of respondents indicate that purchasing can be rated as one of the most important services. Most New Zealand 3PL users have realized how important the purchasing function is within their businesses. Cross-docking service is perceived as the least important outsourcing service.

\subsection{The measurement model}

A set of analyses was employed to test the reliability and validity of constructs after data collection. We used SPSS and AMOS 19 for statistical analysis.

\subsubsection{Unidimensionality and reliability}

We used two-step methods to test the construct reliability (Narasimhan and Jayaram, 1998). First, unidimensionality of the scales was examined by using exploratory factor analysis (EFA). Second, the data reliability was assessed by using Cronbach’s Alpha $(\alpha)$. EFA with Varimax rotation was used to determine the major constructs measured by the items. Cronbach's Alpha $(\alpha)$ was used to assess the internal consistency of each construct (Nunnally, 1978). These tests indicated results within acceptable ranges.

According to the result of EFA (Table 3), there are at least three measured variables to explain each construct in the samples of 3PL users. This indicates appropriate loading of the survey items onto the variables. 
Table 3 Exploratory factor analysis for New Zealand 3PL users

\begin{tabular}{|c|c|c|c|c|c|c|c|}
\hline & \multicolumn{7}{|c|}{ 3PL Users } \\
\hline & Procurement & $\begin{array}{c}\text { Value to } \\
\text { client }\end{array}$ & Uncertainty & $\begin{array}{c}\text { Asset } \\
\text { specificity }\end{array}$ & Frequency & Size & \begin{tabular}{|c} 
Benefit to \\
3PL provider
\end{tabular} \\
\hline NU-Cord & .162 & .138 & .097 & .781 & .039 & .052 & .147 \\
\hline NU-ComPos & .143 & .141 & -.041 & .822 & .070 & .064 & .067 \\
\hline NU-TimEff & .149 & .098 & -.020 & .780 & -.006 & -.041 & .188 \\
\hline NU-Rout & .011 & .064 & .062 & .789 & .104 & .118 & -.075 \\
\hline NU-Demo & .033 & -.035 & .882 & -.027 & -.064 & .038 & .112 \\
\hline NU-Conf & .069 & -.089 & .881 & -.025 & -.026 & .080 & .138 \\
\hline NU-Req & .098 & -.056 & .805 & .093 & .128 & .144 & .156 \\
\hline NU-Const & .039 & -.016 & .814 & .065 & .213 & .150 & .114 \\
\hline NU-OrdFr & .067 & -.010 & .118 & .117 & .858 & .070 & .054 \\
\hline NU-Moni & .064 & .034 & .016 & .132 & .863 & .039 & .156 \\
\hline NU-FreInc & .143 & .122 & .058 & -.049 & .837 & .104 & -.023 \\
\hline NU-Bene & .029 & .012 & .120 & -.016 & .112 & .867 & -.004 \\
\hline NU-Vol & .113 & -.102 & .225 & .092 & .019 & .790 & .136 \\
\hline NU-Conso & -.046 & .099 & .045 & .124 & .084 & .862 & .134 \\
\hline NU-PA-Cat & .797 & .109 & .112 & .034 & .053 & .064 & .008 \\
\hline NU-PA-Mgk & .888 & .042 & -.078 & .088 & -.006 & .065 & .060 \\
\hline NU-PA-Qua & .766 & .079 & .109 & .051 & .029 & .180 & -.120 \\
\hline NU-PA-Pro & .891 & .020 & .057 & .054 & .004 & -.049 & .112 \\
\hline NU-PA-Bid & .785 & .039 & .080 & .133 & .059 & -.029 & .067 \\
\hline NU-PA-Cos & .746 & .050 & .049 & .062 & .158 & -.005 & .107 \\
\hline NU-PA-Sup & .801 & -.073 & -.052 & .112 & .045 & -.081 & .119 \\
\hline NU-SO-Cos & .101 & .816 & -.072 & .012 & .075 & .135 & .009 \\
\hline NU-SO-Fle & .018 & .753 & -.092 & .166 & .053 & -.137 & -.133 \\
\hline NU-SO-Ser & .060 & .894 & -.040 & .082 & .017 & .039 & .089 \\
\hline NU-SO-Emp & .025 & .802 & .014 & -.006 & .017 & .013 & .221 \\
\hline NU-SO-Com & .025 & .736 & -.063 & .186 & .000 & -.075 & -.017 \\
\hline NU-MaiRel & .020 & .814 & .042 & .049 & .012 & .043 & .043 \\
\hline NU-ShaPur & .245 & .125 & .107 & .091 & .045 & .096 & .704 \\
\hline NU-SucOut & .060 & .023 & .224 & .146 & -.004 & .122 & .802 \\
\hline NU-ComWor & .005 & .038 & .177 & .062 & .150 & .045 & .817 \\
\hline $\begin{array}{l}\text { Total variance } \\
\text { explained }\end{array}$ & & & & $71.84 \%$ & & & \\
\hline
\end{tabular}

In the CFA model, the researcher used maximum-likelihood estimation to justify the factor structure. The model fit indices for 3PL users are $\chi^{2}(373)=454.330, p<0.001$; the normed ChiSquare $=1.218 ; \mathrm{CFI}=0.97 ; \mathrm{IFI}=0.97 ; \mathrm{TLI}=0.96 ;$ and, RMSEA $=0.037$, indicating that both models were acceptable. All factor loadings were greater than 0.50 and highly significant at p-value less than 0.001 (Hair et al., 2010). 
Table 4 illustrates the values of Cronbach's Alpha $(\alpha)$, composite reliability, and variance extracted for the 3PL users. All Cronbach's Alpha $(\alpha)$ and composite reliability are above 0.70, and the values of variance extracted are greater than 0.50 . Therefore, convergent validity is established.

Table 4 Cronbach's Alpha ( $\alpha$ ) and composite reliability for New Zealand 3PL users

\begin{tabular}{|c|c|c|c|c|c|}
\hline Construct & Indicator & $\begin{array}{c}\text { Standardized } \\
\text { weight }\end{array}$ & $\begin{array}{c}\text { Cronbach's } \\
\text { Alpha }(\alpha)\end{array}$ & $\begin{array}{c}\text { Composite } \\
\text { reliability }\end{array}$ & $\begin{array}{c}\text { Variance } \\
\text { extracted }\end{array}$ \\
\hline \multirow[t]{4}{*}{ AS } & NURout - AS & 0.623 & 0.835 & 0.827 & 0.547 \\
\hline & NUTimEff - AS & 0.769 & & & \\
\hline & CUComPos - AS & 0.746 & & & \\
\hline & NUCord - AS & 0.821 & & & \\
\hline \multirow[t]{4}{*}{ UN } & NUConst - UN & 0.877 & 0.892 & 0.872 & 0.634 \\
\hline & NUReq - UN & 0.868 & & & \\
\hline & NUConf - UN & 0.621 & & & \\
\hline & NUDemo - UN & 0.754 & & & \\
\hline \multirow[t]{3}{*}{ FR } & NUFreInc - FR & 0.792 & 0.843 & 0.800 & 0.642 \\
\hline & NUMoni - FR & 0.781 & & & \\
\hline & NUOrdFr - FR & 0.657 & & & \\
\hline \multirow[t]{3}{*}{ SZ } & NUConso - SZ & 0.807 & 0.830 & 0.879 & 0.754 \\
\hline & NUVol - SZ & 0.78 & & & \\
\hline & NUBene - SZ & 0.794 & & & \\
\hline \multirow[t]{7}{*}{ PROCU } & NUPAQua - PROCU & 0.662 & 0.918 & 0.890 & 0.540 \\
\hline & NUPAMgk - PROCU & 0.841 & & & \\
\hline & NUPACat - PROCU & 0.68 & & & \\
\hline & NUPAPro - PROCU & 0.955 & & & \\
\hline & NUPABid - PROCU & 0.657 & & & \\
\hline & NUPACos - PROCU & 0.693 & & & \\
\hline & NUPASup - PROCU & 0.744 & & & \\
\hline \multirow[t]{3}{*}{ BT3PL } & NUComWor - BT3PL & 0.786 & 0.759 & 0.818 & 0.604 \\
\hline & NUSucOut - BT3PL & 0.797 & & & \\
\hline & NUShaPur - BT3PL & 0.604 & & & \\
\hline \multirow[t]{6}{*}{ VTC } & NUSOSer - VTC & 0.903 & 0.895 & 0.903 & 0.616 \\
\hline & NUSOFle - VTC & 0.606 & & & \\
\hline & NUSOCos -VTC & 0.843 & & & \\
\hline & NUSOEmp -VTC & 0.766 & & & \\
\hline & NUSOCom -VTC & 0.536 & & & \\
\hline & NUMaiRel - VTC & 0.721 & & & \\
\hline \multicolumn{6}{|c|}{ Notes: $\chi^{2}(373)=454.330, \chi 2 / \mathrm{df}=1.218, \mathrm{CFI}=0.97, \mathrm{RMSEA}=0.037$. All are significant $(\mathrm{p}<0.001)}$. \\
\hline
\end{tabular}




\subsubsection{Validity}

For the validity test, we compared the average variance-extracted values for any two constructs with the square of the correlation estimate between these two constructs (Fornell and Larcker, 1981). In Table 5, the values on the diagonal are obtained from the variance extracted. According to the computations, inter-correlations between each construct are moderate, representing items assigned to one construct were not significantly loading on others. Therefore, discriminant validity is established.

Table 5 Discriminant validity for New Zealand 3PL users

\begin{tabular}{|c|l|l|l|l|l|l|l|}
\hline & \multicolumn{1}{|c|}{ AS } & \multicolumn{1}{|c|}{ UN } & FR & SZ & PROCU & VTC & BT3PL \\
\hline AS & 0.547 & & & & & & \\
\hline UN & $0.155^{* *}$ & 0.634 & & & & & \\
\hline FR & $0.179^{* * *}$ & $0.391^{* *}$ & 0.642 & & & & \\
\hline SZ & $0.162^{*}$ & $0.364^{* * *}$ & $0.228^{*}$ & 0.754 & & & \\
\hline PROCU & $0.252^{* *}$ & $0.179^{* *}$ & $0.188^{* *}$ & $0.044^{* *}$ & 0.54 & & \\
\hline VTC & $0.326^{* *}$ & $0.444^{* *}$ & $0.231^{* *}$ & $0.295^{* *}$ & $0.218^{* *}$ & 0.604 & \\
\hline BT3PL & $0.269^{* *}$ & $0.031^{*}$ & $0.127^{* *}$ & $0.047^{*}$ & $0.127^{* *}$ & $0.152^{* *}$ & 0.616 \\
\hline
\end{tabular}

Note: $* P<0.05 * * P<0.01 * * * P<0.001$

\subsection{SEM results}

Based on the overall assessment of the measurement model, this section emphasizes the SEM and testing of the hypothesized relationships. AMOS 19 was employed to analyse and assess each hypothesis by reviewing the direction and significance in the AMOS results.

The fit statistics show that the structural model for 3PL users was acceptable $(\chi 2(393)=613.199$, $\mathrm{p}<0.001$; the normed Chi-Square $=1.560 ;$ CFI $=0.92 ;$ IFI $=0.92 ;$ TLI $=0.91 ;$ and, RMSEA $=$ 0.059). AMOS outputs on hypothesized paths' standardized regression weights with the relevant critical ratio (CR), and p-values were then examined to test the individual hypotheses. Table 6 provides the results of the structural model tested. 
The relationship between uncertainty and procurement is significant $(b=0.202, p<0.05$ ), supporting H2b. However, the path loadings from asset specificity, frequency, and size to procurement are not significant $(b=0.077, b=0.145, b=0.079, n s)$, suggesting rejection of $H 1, H 3$, and H4. The influence of procurement on value-to-client and benefit-to-provider is significant $(b=$ 0.22 and $0.127, \mathrm{p}<0.05)$. Thereby, the hypotheses of H5 and H6 are supported.

Table 6 Hypothesized path testing for New Zealand 3PL users

\begin{tabular}{clcccc}
\hline Path & & $\begin{array}{c}\text { Standardized } \\
\text { weight }\end{array}$ & CR & p & Note \\
\hline H1 & Asset specificity $\rightarrow$ Procurement & 0.077 & 1.293 & 0.196 & Not significant \\
H2 & Uncertainty $\rightarrow$ Procurement & 0.202 & 2.099 & $0.036<0.05$ & Supported \\
H3 & Frequency $\rightarrow$ Procurement & 0.145 & 1.656 & 0.098 & Not significant \\
H4 & Size $\rightarrow$ Procurement & 0.079 & 1.293 & 0.196 & Not significant \\
H5 & Procurement $\rightarrow$ Value-to-client & 0.22 & 2.485 & $0.013<0.05$ & Supported \\
H6 & Procurement $\rightarrow$ Benefit-to-provider & 0.127 & 1.567 & $0.017<0.05$ & Supported \\
\hline
\end{tabular}

\subsection{Discussion}

We found no significant relationship between asset specificity and 3PP service. This contrasts with the findings by Hanna and Maltz (1998) in their research of logistics providers' expansion into warehousing service. They found a significant relationship between asset specificity and a new service providing. Our different results can be explained by considering the different natures of the services that we examined relative to those examined by Hanna and Maltz. Offering warehousing services requires logistics providers to invest warehousing facilities, but the implementation of 3PP service relies on the availability of expertise. In New Zealand, 3PL users think that a more economical way to obtain qualified purchasing experts for 3PL providers is using human resource professional websites. Alternatively, 3PL providers consider recruiting purchasing professionals 
from 3PL users' companies, so they do not need to make substantial investments in recruiting purchasing experts. 3PL users think that their logistics providers do not need to invest additional capital in improving their logistics facilities. Exchanging virtual information has changed the traditional business style, so it is not required for 3PL providers to build a distribution centre close to their customers. The current relationships between 3PL providers and users are good, and 3PL users do not expect that their logistics providers need to put more effort into improving the relationships. The 3PL providers can accurately understand what their customers want and need. Thereby, asset specificity is not a significant factor in the decision of outsourcing procurement function.

We found that the relationship between uncertainty and 3PP service was significant. This is similar to the findings by Bienstock and Menzter's (1999) in their study of outsourcing distribution and logistics services in the automotive supplier industry. 3PL users can share some forecasting data and purchasing volumes information with 3PL providers. The annual demand is significantly changed since 3PL users conduct the demand forecasts over the next few years. 3PL providers help them control the progress of purchasing to gain various benefits of using a 3PP service; e.g., reduced purchasing and administrative costs. Also, 3PL providers help their customers to conduct international sourcing and obtain the best price, based on the customers' requirements. The combined size of the New Zealand market is small, so the overall change in orders volumes is insignificant.

The relationship between frequency and 3PP service is not significant; this contrasts with the findings of Hanna and Maltz (1998). 3PL users think they need a certain level of inventory to meet volatile market demand and are more flexible to respond to market change. The outsourced or purchased products are therefore not critical items. 3PL users do not need invest more time and costs in frequently evaluating the purchasing performance of 3PL providers. 3PL users perceive that the bargaining power achieved by their logistics providers is associated with the size of orders rather 
than order frequency. 3PL providers should be more interested in the purchasing volumes rather than frequency.

We found that the relationship between transaction size and 3PP service was not significant. 3PL users do not see the substantial orders consolidated by 3PL providers. 3PL users are not sure whether their 3PL providers can establish the strengths of large transaction size at the present stage since most 3PL providers do not offer this service. Theoretically, transaction costs for small orders tend to be relatively greater, so 3PL users expect that their logistics providers can combine purchase orders to keep transaction costs low and to obtain more bargaining power. However, 3PL users share a concern at the level of their 3PL providers’ competence to aggregate purchase orders.

The relationship between 3PP service and value-to-client is significant. 3PL users can obtain a cheaper purchasing price and consolidation of freight. Offering 'one-stop' service by their 3PL providers helps them manage the entire operational process and enable to focus on their core businesses. Additionally, 3PL users do not need to worry about the high level of purchasing risk, and they do not need to deal with complicated purchasing processes. The associated purchasing activities are outsourced to 3PL providers.

The relationship between 3PP service and benefit-to-3PL provider is significant. 3PL users perceive that their logistics providers increase their leveraging power through consolidating purchasing orders. This gives more confidence for their logistics providers to reduce the purchasing price. Their 3PL providers can increase their annual revenues, expand into new markets, and maintain their customer loyalty. Implementation of 3PP service helps 3PL providers integrate their current business and attract more customers to use their integrated services.

\subsection{Managerial implications}

We have several general propositions based on the survey findings mentioned above. First, the investment in 3PP service by 3PL providers is low, particularly as 3PL providers do not require 
substantial investment to establish a 3PP. Second, the market change is slow, based on the small population. Therefore, 3PL providers can accurately forecast future purchasing demand. Third, from the practical perspective, 3PL users must hold a certain level of inventory to meet uncertain market demand, so the purchase orders are not placed frequently. They believe that the increase of frequency cannot increase the purchasing power of their 3PL providers since the logistics providers believe that volume is the key to leverage. Fourth, 3PL users are concerned with the ability of 3PL providers to obtain a large transaction size by aggregating small orders. They are not sure whether their 3PL providers can find a balance point during the bargaining process to reduce purchasing costs. Finally, offering 3PP service provides mutual benefits for both 3PL users and their 3PL providers.

Also, the model suggests several proposed managerial implications, including: first, most 3PL users are interested in using 3PP service. Potentially, users are confident that the associated activities of purchasing and negotiation can be outsourced to 3PL providers. Consolidation of freight saves more than just operational costs. Most SMEs do not have substantial bargaining power and their 3PL providers can offer 'one-stop’ service; e.g., combined purchasing, tracking, warehousing, and transportation services. 3PL users may rely on their 3PL providers' understanding of the markets and costs.

Second, the concept of 3PP services implemented by 3PL providers can be successful. 3PL providers can aggregate orders from multiple users and create integrated service offerings. Also, the 3PLs can improve negotiation and contracting with suppliers to derive lower prices for their customers. Presently, many businesses tend to use this approach, internationally (Gruijssen et al., 2007). Combining buying power would be advantageous for 3PL providers in obtaining low purchasing costs and locking in more customers. 3PL providers have to offer the right systems, to the right people and establish the right contacts for outsourcing markets.

Third, there are two points needed to be considered by 3PL providers. First, 3PL providers may need to expand the current contacts in other markets since sourcing frequently requires them to have 
more relationships and contacts in different regions. Second, 3PL providers must demonstrate their abilities to gain purchasing scale through greater order quantities. Purchasing scale is crucial when establishing a 3PP service.

\section{Conclusions}

SMEs are likely to use 3PP services, to further reduce their costs by gaining improved purchase prices associated with the greater (combined) purchasing volumes of the 3PL provider. To overcome the small purchasing quantities and limited negotiation power of SMEs, 3PL providers can lower the costs of items purchased on behalf of their customers through consolidating the purchase orders. Extending into this new market is a good option for 3PL providers based in competitive markets in the logistics industry. This research focuses on 3PP service offered by 3PL providers and investigated from the perspective of 3PL users. Leading 3PL providers expect to be soon offering 3PP services to maximize further their use of their logistics facilities capacity and reduce their operational costs through integrated logistics systems. 3PL users are interested in using 3PP service and support the concept of a 'one-stop' service offered by 3PL providers. Consolidation of freight can support greater operational costs savings and enables 3PL users to focus on core competencies to support market differentiation.

This research makes several key contributions. First, no other studies address 3PP service offered by 3PL providers. This is pioneering research to investigate the perception of 3PP services from the perspective of 3PL users. Second, this research employs TCA at the firm-level to research the procurement function. Most existing studies focus on TCA at the transaction level. Third, the survey results suggest that the potential market for 3PP service is large, providing mutual benefits for 3PL users and their logistics providers.

There are three limitations of this research. First, this research only focuses on TCA; further studies may use other organizational theories; e.g., resource-based view (RBV). Second, this 
research uses only four major factors associated with 3PP services. Future studies may explore additional factors that may influence 3PP service; e.g., the cycle period of customers’ purchasing and the levels of trust. Third, we focus on 3PP as an additional service from 3PLs; future studies should explore other additional services; e.g., customized logistics solutions. Future research should examine how and why the uptake of value-added services by 3PLs differs by country and region, complementing the research on differences in logistics outsourcing. 


\section{References}

Adobor, H. and McMullen, R. S. (2014), "Strategic purchasing and supplier partnerships —The role of a third party organization”, Journal of Purchasing and Supply Management, Vol. 20 No. 4, pp. 263-272.

Arlbjørn, J. S. and Paulraj, A. (2013), “Special topic forum on innovation in business networks from a supply chain perspective: Current status and opportunities for future research”, Journal of Supply Chain Management, Vol. 49 No. 4, pp. 3-11.

Arroyo, P., Gaytan, J. and Boer, L. de. (2006), “A survey of third party logistics in Mexico and a comparison with reports on Europe and USA”, International Journal of Operations \& Production Management, Vol. 26 No. 6, pp. 639-667.

Anderson, E. (1985), “The salesperson as outside agent or employee: A transaction cost analysis”, Marketing Science, Vol. 4 No. 3, pp. 234-254.

Anderson, E. J., Coltman, T., Devinney, T. M. and Keating, B. (2011), “What drives the choice of a third-party logistics provider?”, Journal of Supply Chain Management, Vol. 47 No. 2, pp. 97115.

Ansari, A. and Modarress, J. R. (2010), “Challenges of outsourcing logistics to third-party providers”, International Journal of Logistics Systems and Management, Vol. 7 No. 2, pp. 198218.

Armstrong, J. S. and Overton, T. S. (1977), “Estimating nonresponse bias in mail survey”, Journal of Marketing Research, Vol. 14 No. 3, pp. 396-402.

Bienstock, C. C. and Mentzer, J. R. (1999), “An experimental investigation of the outsourcing decision for motor carrier transportation”, Transportation Journal, Vol. 39 No. 1, pp. 42-59.

Bookbinder, J. H. and Tan, C. S. (2003), “Comparison of Asian and European logistics systems”, International Journal of Physical Distribution \& Logistics Management, Vol. 33 No. 1, pp. 36-58.

Brewer, B., Wallin, C. and Ashenbaum, B. (2014), "Outsourcing the procurement function: Do actions and results align with theory?”, Journal of Purchasing and Supply Management, Vol. 20 No. 3, pp. 186-194.

Coase, R. H. (1937), “The nature of the firm”, Economica, Vol. 4 No. 16, pp. 386-405. 
Cook, T. and Campbell, D. (1979), Quasi-experimentation: Design and Analysis Issues, Rand McNally, Chicago.

Ellegaard, C. (2006), “Small company purchasing: A research agenda”, Journal of Purchasing \& Supply Management, Vol. 12 No.5, pp. 272-283.

Ellram, L. M., Tate, W. L. and Billington, C. (2008), “Offshore outsourcing of professional services: A transaction cost economics perspective”, Journal of Operations Management, Vol. 26 No. 2, pp. 148-163.

Fornell, C. and Larcker, D. F. (1981), "Evaluating structural equation models with unobservable variables and measurement error”, Journal of Marketing Research, Vol. 18 No. 1, pp. 29-50.

Gattorna, J., Day, A. and Hargreaves, J. (1991), “Effective logistics management”, Logistics Information Management, Vol. 4 No. 2, pp. 2-86.

Goldsby, T. J. and Eckert, J. A. (2003), “Electronic transportation marketplaces: A transaction cost perspective”, Industrial Marketing Management, Vol. 32 No. 3, pp. 187-198.

Gotzamani, K., Longinidis, P. and Vouzas, F. (2010), “The logistics services outsourcing dilemma: Quality management and financial performance perspective”, Supply Chain Management: An International Journal, Vol. 15 No. 6, pp. 438-453.

Grover, V. And Malhotra, M. K. (2003), “Transaction cost framework in operations and supply chain management research: Theory and measurement”, Journal of Operations Management, Vol. 21 No. 4, pp. 457-473.

Gruijssen, F., Cools, M. and Dullaert, W. (2007), “Horizontal cooperation in logistics: Opportunities and impediments”, Transportation Research Part E, Vol. 43 No. 2, pp. 129-142.

Hanna, J. B. and Maltz, A. (1998), "LTL expansion into warehousing: A transaction cost analysis", Transportation Journal, Vol. 38 No. 2, pp. 5-17.

Hofer, A. R., Knemeyer, M. and Dresner, M. E. (2009), “Antecedents and dimensions of customer partnering behaviour in logistics outsourcing relationships”, Journal of Business Logistics, Vol. 30 No. 2, pp. 141-159.

Holter, A. R., Grant, D. B., Ritchie, J. and Shaw, N. (2008), “A framework of purchasing transport services in small and medium size enterprises”, International Journal of Physical Distribution and Logistics Management, Vol. 38, No. 1, pp. 21-38.

Hudson, R. L. and McArthur, A. W. (1994), "Contracting strategies in entrepreneurial and established firms”, Entrepreneurship Theory and Practice, Vol. 18 No. 3, pp. 43-59.

Kaiser, H. F. (1970), “A second-generation little Jiffy”, Psychometrika, Vol. 35 No. 4, pp. 401-415.

Knemeyer, A. M. and Murphy, P. R. (2005), "Is the glass half full or half empty? An examination of user and provider perspectives towards third-party logistics relationships”, International 
Journal of Physical Distribution \& Logistics Management, Vol. 35 No. 10, pp. 708-727.

Lambert, D. M., Emmelhainz, M. A., \& Gardner, J. T. (1999). "Building successful logistics partnerships”, Journal of Business Logistics, Vol. 20, No. 1, 165-181.

Larsen, T. S. (2000), “Third-party logistics from an interorganizational point of view”, International Journal of Physical Distribution \& Logistics Management, Vol. 30 No. 2, pp. 112-127.

Lieb, R. C., Millen, R. A. and Wassenhove, L. N. V. (1993), “Third party logistics services: A comparison of experienced American and European manufacturers”, International Journal of Physical Distribution \& Logistics Management, Vol. 23 No. 6, pp. 35-44.

Light, E. (2001), “3PL: Where it’s at, where it’s going and why”, NZ Business, Vol. 5 No.2, p. 43.

Leuschner, R., Carter, C. R., Goldsby, T. J. and Rogers, Z. S. (2014), “Third-party logistics: A metaanalytic review and investigation of its impact on performance”, Journal of Supply Chain Management, Vol. 50 No. 1, pp. 21-43.

Maltz, A. (1994), “Outsourcing the warehousing function: Economic and strategic considerations”, The Logistics and Transportation Review, Vol. 30 No. 3, pp. 245-265.

Maltz, A. (1993), “Private fleet use: A transaction cost model”, Transportation Journal (American Society of Transportation \& Logistics Inc), Vol. 32 No. 3, pp. 46-53.

Masten, S.E. (1984), “The organization of production: Evidence from the aerospace industry”, Journal of Law and Economics, Vol. 27 No. 2, pp. 403-417.

Mclvor, R. (2009), "How the transaction cost and resource-based theories of the firm inform outsourcing evaluation”, Journal of Operations Management, Vol. 27 No. 1, pp.45-63.

Millen, R., Sohal, A., Dapiran, P., Lieb, R. and Van Wassenhove, L. N. (1997), “Benchmarking Australian firms’ usage of contract logistics services: A comparison with American and Western European practice”, Benchmarking for Quality Management \& Technology, Vol. 4 No. 1, pp. 34-46.

Narasimhan, R. and Jayaram, J. (1998), “Causal linkages in supply chain management: An exploratory study of North American manufacturing firms”, Decision Sciences, Vol. 29 No. 3, pp. 579-605.

Nunnally, J. C. (1978), Psychometric Theory, McGraw-Hill, New York.

New Zealand Inland Revenue. (2010), “Compliance focus 2010-2011”, available at http://www.ird.govt.nz/resources/3/c/3cffb480433082bf90f6f75d5f60e4be/our-compliancefocus-2010-11.pdf (accessed 13 August, 2015).

Panayides, P. M. and So, M. (2005), “Logistics service provider - client relationships”, Transportation Research Part E, Vol. 41 No. 3, pp. 179-200. 
Park, D. and Krishnan, H. A. (2001), "Supplier selection practices among small firms in the United States: Testing three models”, Journal of Small Business Management, Vol. 39 No. 3, pp. 259271.

Podsakoff, P. M. and Organ, D. W. (1986), "Self-reports in organizational research: Problem and prospects”, Journal of Management, Vol. 12 No. 4, pp. 531-544.

Pring, B. (2006), Procurement BPO holds promise but needs help to achieve efficiencies (ID Number: G00138866), Retrieved from Gartner.

Rabinovich, E., Knemeyer, A. M. and Mayer, C. M. (2007), "Why do Internet commerce firms incorporate logistics service providers in their distribution channels? The role of transaction costs and network strength”, Journal of Operations Management, Vol. 25 No. 3, pp. 661-681.

Rahman, S. (2008). "Quality management in logistics services: A comparison of practices between manufacturing companies and logistics firms in Australia”, Total Quality Management and Business Excellence, 19(5), 535-550.

Reeves, K. A., Caliskan, F. and Ozcan, O. (2010), “Outsourcing distribution and logistics services within the automotive supplier industry”, Transportation Research Part E, Vol. 46 No. 3, pp. 459-468.

Rozemeijer, F. (2000), "How to manage corporate purchasing synergy in a decentralised company? Towards design rules for managing and organizing purchasing synergy in decentralised companies”, European Journal of Purchasing \& Supply Management, Vol. 6 No. 1, pp. 5-12.

Salleh, A. L., Arabia, S. and Dali, A. (2009), “Third party logistics service providers and logistics outsourcing in Malaysia”, The Business Review, Vol. 13 No. 1, pp. 264-270.

Sankaran, J., Mun, D. and Charman, Z. (2002), “Effective logistics outsourcing in New Zealand: An inductive empirical investigation”, International Journal of Physical Distribution and Logistics Management, Vol. 32 No. 8, pp. 682-702.

Schoenherr, T., Modi, S. B., Benton, W. C., Carter, C. R., Choi, T. Y., Larson, P. D., Leenders, M. R., Mabert, V. A., Narasimhan, R., and Wagner, S. M. (2012), "Research opportunities in purchasing and supply management”, International Journal of Production Research, Vol. 50 No. 16, pp. 4556-4579.

Schotanus, F. and Telgen J. (2007), “Developing a typology of organizational forms of cooperative purchasing”, Journal of Purchasing and Supply Management, Vol. 13 No. 1, pp. 53-68.

Scully, J. I. and Fawcett, S. E. (1994), “International procurement strategies: Challenges and opportunities for the small firm”, Production and Inventory Management Journal, Vol. 35 No. 2, pp. 39-46. 
Sink, H. L. and Langley, C. J. (1997), “A managerial framework for the acquisition of third-party logistics services”, Journal of Business Logistics, Vol. 18 No. 2, pp. 163-189.

Smyth, H. (2005), "Procurement push and marketing pull in supply chain management: The conceptual contribution of relationship marketing as a driver in project financial performance”, Journal of Financial Management of Property and Construction, Vol. 10 No. 1, pp. 33-44.

Sohail, M. S., Bhatnagar, R. and Sohal, A. S. (2006), “A comparative study on the use of third party logistics services by Singaporean and Malaysian firms”, International Journal of Physical Distribution \& Logistics Management, Vol. 36 No. 9, pp. 690-701.

Stump, R. L. (1995),” Antecedents of purchasing concentration: A transaction cost Explanation”, Journal of Business Research, Vol. 34, pp. 145-157.

Tella, E. and Virolainen, V. M. (2005), “Motives behind purchasing consortia”, International Journal of Production Economics, Vol. 93-94 No. 8, pp. 161-168.

Verwaal, E. and Donkers, B. (2003), “Customs-related transaction costs, firm size and international trade intensity”, Small Business Economics, Vol. 21 No. 3, pp. 257-271.

Vining, A. and Globerman, S. (1999), “A conceptual framework for understanding the outsourcing decision”, European Management Journal, Vol. 17 No. 6, pp. 645-654.

Wagner, S. M., Eggert, A. and Lindemann, E. (2010), “Creating and appropriating value in collaborative relationships”, Journal of Business Research, Vol. 63 No. 8, pp. 840-848.

Wagner, S. M. and Sutter, R. (2012), “A qualitative investigation of innovation between third--party logistics providers and customers”, International Journal of Production Economics, Vol. 140 No. 2, pp. 944-958.

Williamson, O. E. (2008), “Outsourcing: Transaction cost economics and supply chain management”, Journal of Supply Chain Management, Vol. 44 No. 2, pp. 5-16.

Williamson, O. E. (1985), The Economic Institutions of Capitalism, Free Press, New York.

Williamson, O. E. (1975), Market and Hierarchies: Analysis and Antitrust Implications, Free Press, New York.

Wilson, M.J. and Roy, R.Y. (2009), “Enabling lean procurement: A consolidation model for smalland medium- sized enterprises”, Journal of Manufacturing Technology Management, Vol. 20 No. 6, pp. 817-833.

Win, A. (2008), “The value a 4PL provider can contribute to an organisation”, International Journal of Physical Distribution \& Logistics Management, Vol. 38 No. 9, pp. 674-684. 
Zhang, Y. (2009), The Usage of Third Party Logistics in New Zealand, Master in Applied Science in Logistics and Supply Chain, Massey University, Albany, New Zealand, available at: http://mro.massey.ac.nz/handle/10179/987 (accessed 9 December 2015).

Zheng, J., Knight, L., Harland, C. and Humby S. (2007), “An analysis of research into the future of purchasing and supply management”, Journal of Purchasing and Supply Management, Vol. 13 No. 1, pp. 69-83. 